\title{
Editorial:
}

\section{Sobukwe, psychology, and politics}

It is a sign of the times that a journal devoting a special issue to the work and ideas of Robert Mangaliso Sobukwe should feel the necessity to "justify" itself, and especially so a psychology journal. What have Sobukwe's ideas got to do with psychology, and even a journal of the social in psychology? Previous special issues of PINS (Psychology in society) have usually come about for two reasons: either to highlight some important social phenomenon (like racism, HIV/AIDS), or to bring attention to some neglected area of investigation (like social cohesion). The work and ideas of Robert Sobukwe have certainly suffered from intellectual neglect, not to mention the marginalization of Africanist thought through the hegemony of the Charterist political project. Mcebisi Ndletyana (2013) has made this point forcefully. He notes that repeated opportunities to commemorate Sobukwe's legacy were met with a telling silence: "This silence tells us, in its own unique way, of an official quest to forget Sobukwe ... Attempts to erase Sobukwe's memory in our public consciousness are indicative of how those in power legitimise themselves." (Ndletyana, 2013: 15).

And yet, we should ask: what might the intersection(s) be between psychology and Sobukwe's work in particular, or Africanist thought in general? As important as this question is, it is not one answered in the present issue of PINS in any full or satisfactory way, but at least some ideas for further consideration have been raised, and hopefully will generate debate around the importance or otherwise of Robert Sobukwe's ideas for psychology and other areas of social study.
Grahame Hayes

University of

KwaZulu-Natal,

Durban

grahame.hayes@gmail.com

\section{Derek Hook}

Duquesne University,

Pittsburgh,

USA

hookd@duq.edu 
Given the current factionalism in South African politics, it would be easy to suggest that because PINS has dedicated a special issue on Robert Sobukwe that the journal has somehow aligned itself with Sobukwe's political project, whatever that might mean in 2016, or more broadly has come out in favour of an Africanist position. It seems that psychology, here and elsewhere, tends to be slow in engaging with the political thought(s) of the day, and does not easily take an activist stance in relation to currents of political thought and the implications for its (psychology's) theory and practice. This sentiment was echoed in a recent editorial in the South African Journal of Psychology by Suntosh Pillay (2016: 156) when he wrote that a "psychological practice that is embedded in a ... grassroots, progressive politics that encourages .... radical dissent is well situated to play a supportive role in the decolonisation movement. However, there is a glaring absence of any visible, meaningful relationship between the discipline of Psychology in general, or critical psychology in particular, and the current progressive politics calling for fundamental social change in South Africa." (emphases added).

And while Sobukwe's ideas might not be seen to be much part of present-day political thinking, and that is part of the problem, his name at least has become a signifier of resistance and de-colonisation for the student movements of \#MustFall. While one might want to question how seriously students are engaging with the writings of their chosen "de-colonial theorists", it is worth considering that the inchoate presence of Sobukwe (and Biko and Fanon) through the numerous \#MustFall movements, if only as a slogan, a rallying call, the appeal to some "other" political authority, or even as graffiti, is at least a hint that some important social phenomenon is underway, and unlikely to be halted anytime soon. It might be putting it too strong, in what Katlego Mkhwanazi (2016: 7) wrote about the presence of political activists' names as graffiti in prominent places on university campuses, that "[a]rtwork like this keeps the names of fallen leaders and their ideologies alive". It would be hard to find a more rousing example of Sobukwe's name being put to a contemporary political cause than the words of Malaika wa Azania (2014): "there is a rapture happening in our country. There is an awakening of black people. There is a sense of consciousness that is slowly but surely creeping into our communities ... the increasing number of service delivery protests ... are a result of disenfranchised masses fighting for the right to humanness. These are people who are refusing to continue living in squalor, to being accessories to corruption, maladministration and mediocre leadership, obese with immorality and a lack of integrity ... These are Sobukwe's disciples, blacks who refuse systematic dehumanisation".

Whatever one makes of how students are interpreting the works of these "fallen leaders", the triumvirate of Sobukwe, Biko, and Fanon, are evocative authorities for the \#MustFall calls for transformation, de-colonisation, Africanisation, and the (re-)assertion of Black consciousness. Take for example the comments of Ayabonga Cawe (2015), clearly 
inspired by the ideas of Sobukwe and the PAC: "the articulation of 'transformation' as a solution has found its most fervent critics among the youth, who are calling rather for 'decolonisation'. The project of decolonization pursued by the youth is a project rooted in a particular understanding of racism and the colonial enterprise.... Remedial action involves not only deterring people from being racist, but actually subverting the power relations that allow for such a situation in the first place. Such subversion requires at a minimum, the resolution of the historic antagonism between blacks and whites in South Africa; the land. It is also an understanding that the resolution of the skewed property relations in South Africa including but not limited to land, without a political, cultural and pedagogic project centered on pan Africanism and black consciousness will not suffice".

Richard Pithouse (2016: 23), a South African scholar immersed in the work of Fanon, has suggested that if "there's a philosopher of the moment, it is, by some distance, Frantz Fanon". Pithouse also points to the unfortunate fact that Fanon's ideas on the nature of anti-colonial struggles and the role of political violence in these struggles have been crudely (mis)interpreted. It is not difficult to see why students would be interested in Fanon's ideas given his penetrating analysis and critique of colonialism, and post-colonial regimes, and yet a lot of intellectual and political work needs to be done to make these ideas applicable and useful to the current political conjuncture in South Africa. Simplifying matters somewhat it is noticeable that the \#Fallists make two claims about their predicament, or the current conjuncture, and one is never quite sure where they are talking from. The first is that their experiences, their hurt, their historical suffering as black people are not being taken seriously, and that they have a right to express them as vigorously and angrily as they see fit. The second claim is that the promise/s of 1994 have not been realised. That there was something of a political revolution in the compromise of the government of national unity, but no economic revolution. More forcefully put it is suggested that the ANC "sold out" to white capitalist interests and so structurally the economy has been tied to the protection of "white interests" or white capital at the expense of ordinary black people. In this scenario Mandela is not the hero of liberation, and hence other "authorities" and inspirations are sought. This much is evident in many of the more overtly polemical appeals to Sobukwe's name, such as that of Bennie Bunsee (2008) who wrote: "It has now become known that Mandela gave the country back to the colonialists, and today they are fighting to retain those privileges. The colonial and imperialist world has turned Mandela into an icon and there is now a preposterous cult of the man. Sobukwe, who spent almost eight years alone, separated from the other political prisoners on Robben Island is given secondary importance". A similar argument, which again calls on Sobukwe as a type of counter-Mandela, is made by Sipho Seepe (2008): "As we enter the period of disillusionment with the so-called rainbow 
nation that excludes the centrality of African content, we need to ... reclaim our heroes, learn from the our past ... Sobukwe's literary and political contributions are a necessary antidote to the meaningless but intoxicating language of rainbowism".

In this context it is not difficult to see why the ideas of Fanon, Sobukwe, and Biko for instance might have appeal. Significantly too, many of the spokespeople for the \#Fallists refer to themselves as Africanists, sometimes spelt Afrikanist, Pan-Africanists, even while they say they are members of the ANC, as well as espousing the black consciousness of Biko. Their rhetoric, actions, and suggestions for transformation of the universities in particular, and the country in general, are explicitly about de-colonisation of the polity, the economy, of systems of knowledge, and of the mind of the oppressed. In this \#Fallist activism there is much talk of liberation and emancipation, or more precisely the absence of any fundamental or radical change in post-apartheid South Africa. These are all big challenges which at least require some rigorous thinking through, as well as a careful reading of the complex ideas of Sobukwe, Fanon, Biko, or whoever, for our time.

The issues of what it means to be free, to be liberated, to be emancipated, to be decolonised are certainly going to occupy our political consciousness and actions for many years to come as we try to build a decent and equitable society. In an interview with Agnes Heller in Budapest in 1998, Simon Tormey (the interviewer) asked her about her view of emancipation, and she replied: "I make a distinction between liberation and emancipation. Liberation is never a singular issue, an issue for the individual. If you want to be liberated from a colonial situation then you cannot do it on your own. There is a collective gesture and collective action here. But I think emancipation is a different issue. I don't believe that the philosophical message of emancipation has relevance for class action and collective action. India could be liberated from colonialism, but it was not emancipated through this action. These are two different things. For example, I don't think that American feminists today are emancipated. Absolutely not, because I think the introduction of women's studies in universities is not emancipation. 'Identity politics' is far from being emancipation. I don't think the reversal of violence is your emancipation. I think emancipation is very difficult, very complicated; but it is not individualistic either, in so far as you don't do it on your own. It has to be an interpersonal thing." (Heller, 1999: 32) Heller raises some crucial concerns for our own time that we would do well to ponder before we too hastily engage in different forms of political action.

Following Heller it seems that there was somewhat of a political liberation in 1994, but the social and historical structures that hold us hostage to racism, oppression, and exploitation are still very much part of post-apartheid South Africa. The EFF (Economic Freedom Fighters) continually reminds its supporters and its opponents that the country did not achieve economic liberation in 1994, and that the economy needs to be

PINS [Psychology in Society] 50, $2016 \mid \mathbf{4}$ 
"liberated" from white capital. Much work needs to be done to determine which social structures we need to be liberated from, and how this liberation can be accomplished and sustained. There is also the question of emancipation which as Heller warns us is not an individualistic thing, but certainly involves the individual acting in certain ways, interpersonal ways she suggests, to free their minds or consciousness, their bodies, and their thoughts from current and historical forms of oppression and exploitation. One might posit a dialectical relation between liberation and emancipation, where we can't have the one without the other, and where a transformatory political practice involves both simultaneously. While liberation might seem an inherently social phenomenon, and emancipation an inherently individual phenomenon, liberation and emancipation are irreducible to a simple social and individual division or separation. In other words, the seemingly psychological practices involved in emancipation will be rendered inert if not coupled with the social practices of liberation.

So a creative and constructive way of reading Sobukwe, Fanon, and Biko, for instance, would be to see what they offer us with regard to the tropes of liberation and emancipation, and their necessary interaction and imbrication. Sobukwe challenges us to think about what it means to be part of Africa, what it means to engage in the politics of decolonisation, as well as freeing ourselves from an ideological whiteness that positions itself as superior. The worst thing that we could do is read Sobukwe ahistorically as we try to use his ideas to help us think politically from a psychosocial vantage point. We make no apology for encouraging a psychosocial and psycho-political reflection on the thought and ideas of Robert Mangaliso Sobukwe, because unless to think, and act, politically, psychology will remain stranded on the sidelines of everyday social life.

\section{Acknowledgement.}

Terblanche Delport was instrumental in planning and conceiving the special issue, in offering review comments on the papers, and in editing and revising the interview with Mogobe Ramose.

\section{References}

Bunsee, (2013) True ideologies of Pan-Africanism will triumph. Sunday Independent, 23 June 2013. http://www.iol.co.za/sundayindependent/true-ideologies-of-panafricanism-will-triumph-1536146

5 PINS [Psychology in Society] 50.2016 
Cawe, Ayabonga (2016) Our poisoned inheritance. Daily Maverick, 1 February 2016. http://www.dailymaverick.co.za/opinionista/2016-02-01-our-poisonedinheritance/?ref=yfp\#.VsBv2Hn2bIU

Heller, A \& Tormey, S (1999) Post-Marxism and the ethics of modernity: Agnes Heller interviewed by Simon Tormey. Radical Philosophy, 94, 29-39.

Ndletyana, Mcebisi (2013) Lest we forget our Struggle heroes. Sunday Independent, 24 March 2013, 15.

Mkhwanazi, K (2016) Paint speaks to power. Mail \& Guardian - Friday, 18-23 March 2016, 7.

Pillay, S R (2016) Silence is violence: (Critical) psychology in an era of Rhodes Must Fall and Fees Must Fall. SA J of Psychology, 46(2), 155-159.

Pithouse, R (2016) Violence: What Fanon really said. Mail \& Guardian, 8-14 April 2016, 23.

Seepe, S (2008) Sobukwe - legacy revisited. Sunday Independent, 27 February 2008. http://www.iol.co.za/news/politics/sobukwe-legacy-revisited-1.391095\#.U615631wbml.

wa Azania, M (2014) Why Robert Sobukwe is not dead, Sunday Independent, 23 February 2014. http://www.iol.co.za/sundayindependent/why-robert-sobukwe-isnot-dead-1.1651306 